\title{
Investigation on the Microstructure and Electrical Properties of the Compositionally Modified PZT Ceramics Prepared by Mixed-Oxide Method
}

\author{
Malika Abba, Ahmed Boutarfaia, Zelikha Necira, Noura Abdessalem, Hayet Menasra, \\ Abdelhek Meklid
}

Laboratory of Applied Chemistry, Department of Science Matter, University of Biskra, Biskra, Algeria.

Email: abbamalika@gmail.com

Received August $17^{\text {th }}, 2013$; revised September $29^{\text {th }}, 2013$; accepted October $16^{\text {th }}, 2013$

Copyright (C) 2013 Malika Abba et al. This is an open access article distributed under the Creative Commons Attribution License, which permits unrestricted use, distribution, and reproduction in any medium, provided the original work is properly cited.

\begin{abstract}
The structural and electrical properties of $\mathrm{Pb}\left[\mathrm{Zr}_{\mathrm{x}} \mathrm{Ti}_{0.95-\mathrm{x}}\left(\mathrm{Mo}_{1 / 3} \mathrm{In}_{2 / 3}\right)_{0.05}\right] \mathrm{O}_{3}$ piezoelectric ceramics system with the composition near the morphotropic phase boundary were investigated as a function of the $\mathrm{Zr} / \mathrm{Ti}$ ratio. Studies were performed on the samples prepared by the conventional method of thermal synthesis of mixed oxides. The materials structure was investigated by X-ray diffractometry to demonstrate the co-existence of the tetragonal and rhombohedral phases. In the present system, the MPB, in which the tetragonal and rhombohedral phases coexist, is in a composition range of $0.47 \leq \mathrm{x} \leq 0.50$. The lattice constants of the a and $\mathrm{c}$ axes for the samples were calculated from the XRD patterns. Microstructure of the sintered ceramics was observed by scanning electron microscopy (SEM) of free surfaces specimens. The relative permittivity, dielectric dissipation, piezoelectric coefficient and electromechanical coupling factor reach at maximum value $\mathrm{x}=0.49\left(\varepsilon_{r}=7300.345\right.$ (at the Curie temperature), $\tan \delta=0.002050, \mathrm{~d}_{31}=94.965 \mathrm{PC} / \mathrm{N}$ and $k_{p}$ $=0.513$ and a Curie temperature of $430^{\circ} \mathrm{C}$ ). These properties are very promising for applications in ultrasonic motors.
\end{abstract}

Keywords: Morphotropic Phase Boundary; Sintering Temperature; Zr/Ti Ratio

\section{Introduction}

Lead zirconate titanate $\mathrm{Pb}(\mathrm{Zr}, \mathrm{Ti}) \mathrm{O}_{3}$, a solid solution of perovskite ferroelectric $\mathrm{PbTiO}_{3}$ and anti-ferroelectric $\mathrm{PbZrO}_{3}$ with different $\mathrm{Zr} / \mathrm{Ti}$ ratio, is an important material that is widely used in electronic sensors, actuators, resonators and filters [1-3]. The materials with a perovskite structure of general formula $\mathrm{ABO}_{3}$ (where $\mathrm{A}=$ mono or divalent ions, $\mathrm{B}=$ tri, tetra or pentavalent ions) have been found to be very useful and interesting for different solid-state devices [4-8]. By making suitable substitution at $\mathrm{A}$ and/or $\mathrm{B}$-site of $\mathrm{ABO}_{3}$ structure, a large number of charge neutral or deficient compounds have been prepared [9-11] which have been found to be very suitable and useful for many industrial applications.

In order to satisfy the requirements of practical applications of ultrasonic motors, many ternary and quaternary solid-solutions such as: $\mathrm{Pb}\left(\mathrm{Mn}_{1 / 3} \mathrm{Nb}_{2 / 3}\right) \mathrm{O}_{3}$-PZT, $\mathrm{Pb}\left(\mathrm{Mn}_{1 / 3} \mathrm{Sb}_{2 / 3}\right) \mathrm{O}_{3}-\mathrm{PZT}, \mathrm{Pb}\left(\mathrm{Cd}_{1 / 3} \mathrm{Nb}_{2 / 3}\right) \mathrm{O}_{3}-\mathrm{PZT}$, $\mathrm{Pb}\left(\mathrm{Mn}_{1 / 3} \mathrm{Nb}_{2 / 3}\right)\left(\mathrm{Ni}_{1 / 3} \mathrm{Nb}_{2 / 3}\right) \mathrm{O}_{3}$-PZT, have been synthesized by the modification or the substitution [12-18].
The influence of technological factors on the width of the co-existence region was investigated on the ternary system $\mathrm{Pb}\left[\mathrm{Zr}_{\mathrm{x}}, \mathrm{Ti}_{(0,95-\mathrm{x})}\left(\mathrm{Mo}_{1 / 3}, \mathrm{In}_{2 / 3}\right)_{0.05}\right] \mathrm{O}_{3}$ by X-ray diffraction by varying the ratio $\mathrm{Zr} / \mathrm{Ti}$. The purpose of this work is to study the influence of sintering temperature on density, porosity and grain size on the ceramic in order to determine the width of co-existence of tetragonal and rhombohedral phases and the exact composition of the MPB rather than to determine the dielectric and the piezoelectric properties of these ceramics near the MPB in detail.

\section{Experimental}

All of the specimens were prepared by the conventional ceramics technologie. The compositions of the

$\mathrm{Pb}\left[\mathrm{Zr}_{\mathrm{x},} \mathrm{Ti}_{(0.95-\mathrm{x})}\left(\mathrm{Mo}_{1 / 3}, \mathrm{In}_{2 / 3}\right)_{0.05}\right] \mathrm{O}_{3}$ system werewith $46 \leq \mathrm{x}$ $\leq 55$. The commercially available $\mathrm{PbO}, \mathrm{ZrO}_{2}, \mathrm{TiO}_{2}$, $\mathrm{MoO}_{3}$ and $\mathrm{In}_{2} \mathrm{O}_{3}$, were used as the raw materials. Mixed oxides, after milling, were calcined at $800^{\circ} \mathrm{C}$ for $2 \mathrm{~h}$ at heating and cooling rates of $2^{\circ} \mathrm{C} / \mathrm{min}$. After calcinations, 
the ground and milled powders were pressed into disks $13 \mathrm{~mm}$ in diameter and about $1 \mathrm{~mm}$ in thickness. Pressed disks of $3 \mathrm{PbO}+2 \mathrm{ZrO}_{2}$ placed in a capped crucible to prevent $\mathrm{PbO}$ evaporation during sintering. Four sintering conditions were selected to be used with both methods ranging $1000^{\circ} \mathrm{C}, 1100^{\circ} \mathrm{C}, 1150^{\circ} \mathrm{C}, 1180^{\circ} \mathrm{C}$ and $1200^{\circ} \mathrm{C}$ for $2 \mathrm{~h}$.

The crystal structure of the samples was analyzed using X-ray diffractometry (XRD; Siemens D500). The voltage and currents ratings used were $40 \mathrm{kV}, 30 \mathrm{~mA}$ respectively, and $\mathrm{CuK} \alpha$ radiation was used. The diffraction data were collected with X-ray scan speed of $0.1^{\circ} \cdot \mathrm{min}^{-1}$. The bulk density was measured using the Archimedes method.

To investigate the electrical properties, the electrodes were made by applying a silver paste on the two major faces of the sintered disks followed by heat treatment at $750^{\circ} \mathrm{C}$ for thirty minutes. The dielectric constant $\varepsilon$ was calculated from the capacitance at a frequency of one $\mathrm{KHz}$. It was measured at temperature ranging from $25^{\circ} \mathrm{C}$ to $400^{\circ} \mathrm{C}$ with a heating rate of one ${ }^{\circ} \mathrm{C} /$ minute by using an impedance analyzer (HP4192A, Heweltt-Packard). The piezoelectric samples firstly were being poled in a silicone oil bath at $120^{\circ} \mathrm{C}$ by applying a d.c. field of thirty $\mathrm{KV} / \mathrm{cm}$ for thirty minutes; and, then, were being cold under the same electric field.

They were aged for twenty-four hours before testing. The electromechanical coupling factor $K_{p}$ was determined by the resonance and anti-resonance technique from the "Equation (1)" [19].

$$
K_{p}=\left[\frac{2.51 \times\left(f_{a}^{2}-f_{r}^{2}\right)}{2 f_{a}^{2}}\right]^{1 / 2}
$$

$f_{a}$ : anti-resonant frequency $(\mathrm{Hz})$.

$f_{r}$ : resonant frequency $(\mathrm{Hz})$.

\section{Results and Discussion}

\subsection{Phase Structure}

The sintered powders were examined by X-ray diffractometry to ensure phase purity and to identify the phases. The phases of the samples were detected using XRD (at room temperature) for several compositions given in Table 1.

It is reported that tetragonal, rhombohedral and T-R phases were identified by an analysis of the peaks 002 (tetragonal), 200 (tetragonal), 200 (rhombohedral)) in the $2 \theta$ range $43^{\circ}-47^{\circ}$.

The splitting of ( $\left(\begin{array}{lll}0 & 0\end{array}\right)$ and $\left(\begin{array}{lll}2 & 0 & 0\end{array}\right)$ peaks indicates that they are the ferroelectric tetragonal phase $(\mathrm{T})$, while the single $\left(\begin{array}{lll}2 & 0 & 0\end{array}\right)$ peak shows the rhombohedral phase (R) Figure 1 [20].

Triplet peaks indicate that the sample consists of a
Table 1. Series of compositions and crystal structure.

\begin{tabular}{|c|c|c|c|c|}
\hline \multirow{2}{*}{ Sample } & \multicolumn{4}{|c|}{ Crystal structure } \\
\hline & $1000^{\circ} \mathrm{C}$ & $1100^{\circ} \mathrm{C}$ & $1150^{\circ} \mathrm{C}$ & $1180^{\circ} \mathrm{C}$ \\
\hline $\mathrm{Pb}\left[\mathrm{Zr}_{0.46} \mathrm{Ti}_{0.49}\left(\mathrm{Mo}_{1 / 3} \mathrm{In}_{2 / 3}\right)_{0.05}\right] \mathrm{O}_{3}$ & $\mathrm{~T}$ & $\mathrm{~T}$ & $\mathrm{~T}$ & $\mathrm{~T}$ \\
\hline $\mathrm{Pb}\left[\mathrm{Zr}_{0.47} \mathrm{Ti}_{0.48}\left(\mathrm{Mo}_{1 / 3} \mathrm{In}_{2 / 3}\right)_{0.05}\right] \mathrm{O}_{3}$ & $\mathrm{~T}+\mathrm{R}$ & $\mathrm{T}$ & $\mathrm{T}$ & $\mathrm{T}+\mathrm{R}$ \\
\hline $\mathrm{Pb}\left[\mathrm{Zr}_{0.49} \mathrm{Ti}_{0.46}\left(\mathrm{Mo}_{1 / 3} \mathrm{In}_{2 / 3}\right)_{0.05}\right] \mathrm{O}_{3}$ & $\mathrm{~T}+\mathrm{R}$ & $\mathrm{T}+\mathrm{R}$ & $\mathrm{T}+\mathrm{R}$ & $\mathrm{T}+\mathrm{R}$ \\
\hline $\mathrm{Pb}\left[\mathrm{Zr}_{0.50} \mathrm{Ti}_{0.45}\left(\mathrm{Mo}_{1 / 3} \mathrm{In}_{2 / 3}\right)_{0.05}\right] \mathrm{O}_{3}$ & $\mathrm{~T}+\mathrm{R}$ & $\mathrm{T}+\mathrm{R}$ & $\mathrm{T}+\mathrm{R}$ & $\mathrm{T}+\mathrm{R}$ \\
\hline $\mathrm{Pb}\left[\mathrm{Zr}_{0.51} \mathrm{Ti}_{0.44}\left(\mathrm{Mo}_{1 / 3} \operatorname{In}_{2 / 3}\right)_{0.05}\right] \mathrm{O}_{3}$ & $\mathrm{~T}+\mathrm{R}$ & $\mathrm{T}+\mathrm{R}$ & $T+R$ & $\mathrm{R}$ \\
\hline $\mathrm{Pb}\left[\mathrm{Zr}_{0.52} \mathrm{Ti}_{0.43}\left(\mathrm{Mo}_{1 / 3} \mathrm{In}_{2 / 3}\right)_{0.05}\right] \mathrm{O}_{3}$ & $\mathrm{~T}+\mathrm{R}$ & $\mathrm{T}+\mathrm{R}$ & $\mathrm{T}+\mathrm{R}$ & $\mathrm{R}$ \\
\hline $\mathrm{Pb}\left[\mathrm{Zr}_{0.54} \mathrm{Ti}_{0.41}\left(\mathrm{Mo}_{1 / 3} \mathrm{In}_{2 / 3}\right)_{0.05}\right] \mathrm{O}_{3}$ & $\mathrm{~T}+\mathrm{R}$ & $\mathrm{T}+\mathrm{R}$ & $\mathrm{R}$ & $\mathrm{R}$ \\
\hline $\mathrm{Pb}\left[\mathrm{Zr}_{0.55} \mathrm{Ti}_{0.40}\left(\mathrm{Mo}_{1 / 3} \mathrm{In}_{2 / 3}\right)_{0.05}\right] \mathrm{O}_{3}$ & $\mathrm{R}$ & $\mathrm{R}$ & $\mathrm{R}$ & $\mathrm{R}$ \\
\hline
\end{tabular}

$\mathrm{T}=$ Tetragonal; $\mathrm{R}=$ Rhombohedral; $\mathrm{T}-\mathrm{R}=$ Tetragonal-Rhombohedral.

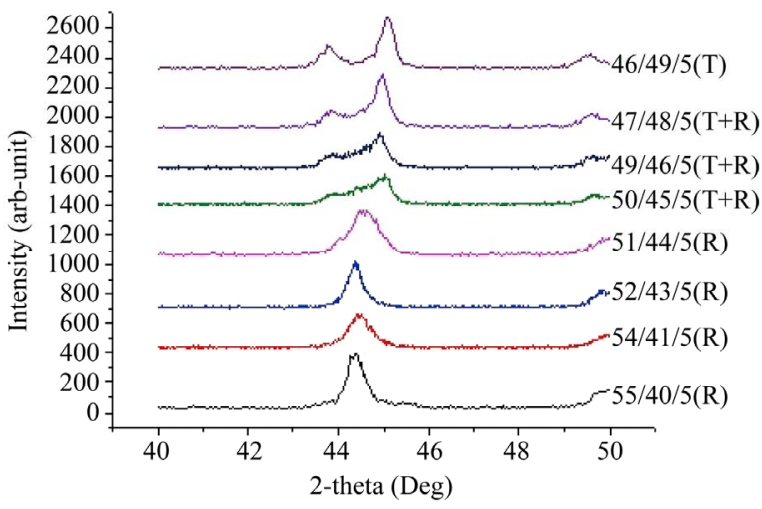

Figure 1. The XRD patterns of $P b$

$\left[\mathrm{Zr}_{\mathrm{x}}, \mathrm{Ti}_{(0.95-\mathrm{x})}\left(\mathrm{Mo}_{1 / 3}, \mathrm{In}_{2 / 3}\right)_{0.05}\right] \mathrm{O}_{3}$ systemwith $0.46 \leq \mathrm{x} \leq \mathbf{0 . 5 5}$.

mixture of tetragonal and rhombohedral phases. The multiple peak separation method was used to estimate the relative fraction of coexisting phases by which the relative phase fraction $M_{R}$ and $M_{T}$ were then calculated using the following Equations (2) and (3) [21]:

$$
\begin{gathered}
M_{R}=\frac{I_{R(200)}}{I_{R(200)}+I_{T(002)}+I_{T(200)}} \\
M_{T}=\frac{I_{T(200)}+I_{T(002)}}{I_{R(200)}+I_{T(002)}+I_{T(200)}}
\end{gathered}
$$

It is clear that, $I_{R(200)}$ is the integral intensity of the (200) reflection of the rhombohedral phase and $I_{T(200)}$, $\mathrm{I}_{\mathrm{T}(002)}$ are the integral intensities of the (200) and (002) reflections of the tetragonal phase, respectively. A transition from tetragonal to rhombohedral phase is observed as $\mathrm{Zr} / \mathrm{Ti}$ ratio increases. With increasing $\mathrm{Zr} / \mathrm{Ti}$ ratio, tetragonal relative fraction decreases and rhombohedral relative fraction increases.

At $1180^{\circ} \mathrm{C}$ Figure 2, it is shown that the tetragonal structure can be formed up to $x_{T}>0.46$, while the rhombohedral structure becomes stabilized for $x_{R}<0.51$. However, at $x=0.46-0.51$ tetragonal and rhombohedral 


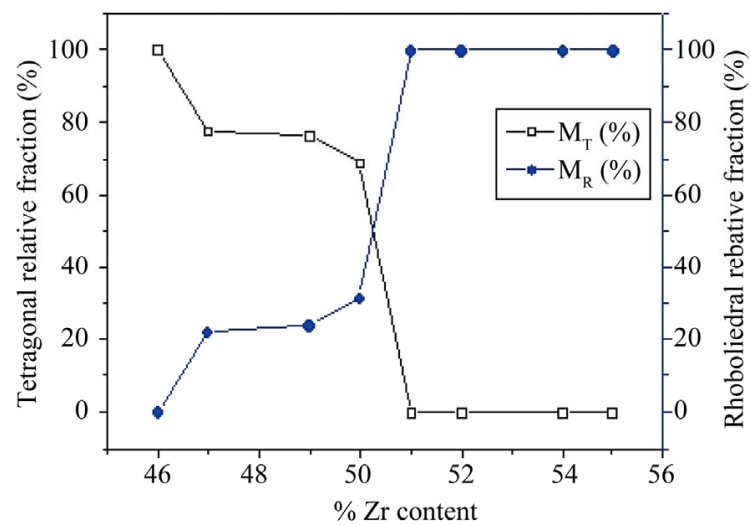

Figure 2. Variation of the relative content of the tetragonal and rhombohedral phases with different $\mathrm{Zr} \%$ in the $\mathrm{Pb}\left[\mathrm{Zr}_{\mathrm{x}} \mathrm{Ti}_{0,95-\mathrm{x}}\left(\mathrm{Mo}_{1 / 3} \mathrm{In}_{2 / 3}\right)_{0.05}\right] \mathrm{O}_{3}$ (for a sintering temperature about $\left.1180^{\circ} \mathrm{C}\right)[20]$.

phases coexist. The co-existence region is therefore quite narrow $(\Delta x \approx 0.05)$ and extends between $x_{T}$ and $x_{R}$. The width $\Delta x=x_{T}-x_{R}$ of the co-existence region from our work is close to that obtained by others $[22,23]$. The coexistence of tetragonal and rhombohedral phases has, therefore, to be attributed to the first order nature of the MPB, this is marked contrast to the proposition of Kakegawa and al. [24,25] that the coexistence is invariably due to compositional fluctuations.

The study of density is necessary to optimize the optimum sintering temperature. The quality of the material increases with the increase of density and it increases with the increase of the sintering temperature [26]. The optimum temperature for sintering is determined from the pattern density as a function of sintering temperature $\mathrm{d}=\mathrm{f}(\mathrm{T})$. So, the maximum density is the product of better quality electrical (low dielectric loss). Figure 3 gathers the curves of the density of all samples depending on the sintering temperature. A similar shape for all curves is that: the density is minimal for a sintering temperature $\mathrm{T}=1000^{\circ} \mathrm{C}$, it begins to grow until it reaches a maximum value at a sintering temperature $\mathrm{T}=1180^{\circ} \mathrm{C}$. Then, it decreases at the sintering temperature $\mathrm{T}=1200^{\circ} \mathrm{C}$ which means that the optimum temperature for sintering is $1180^{\circ} \mathrm{C}$. The increased density means fewer and pore size, so the volume of the cell decreases and consequently the structure becomes more compact.

The optimum sintering temperature depends on several factors such as the addition of impurities, the rate of heating, time of thermal treatment and protecting atmosphere.

Changes in the density of different samples of $\mathrm{Pb}\left[\mathrm{Zr}_{\mathrm{x}} \mathrm{Ti}_{0,95-\mathrm{x}}\left(\mathrm{Mo}_{1 / 3} \mathrm{In}_{2 / 3}\right)_{0.05}\right] \mathrm{O}_{3}$ sintered at $1180^{\circ} \mathrm{C} \mathrm{de}-$ pending on the rate of $\mathrm{Zr}$ is shown in Figure 4.

The shape of the curve shows that the density increases with the increase of $\mathrm{Zr}$ concentration until a maximum

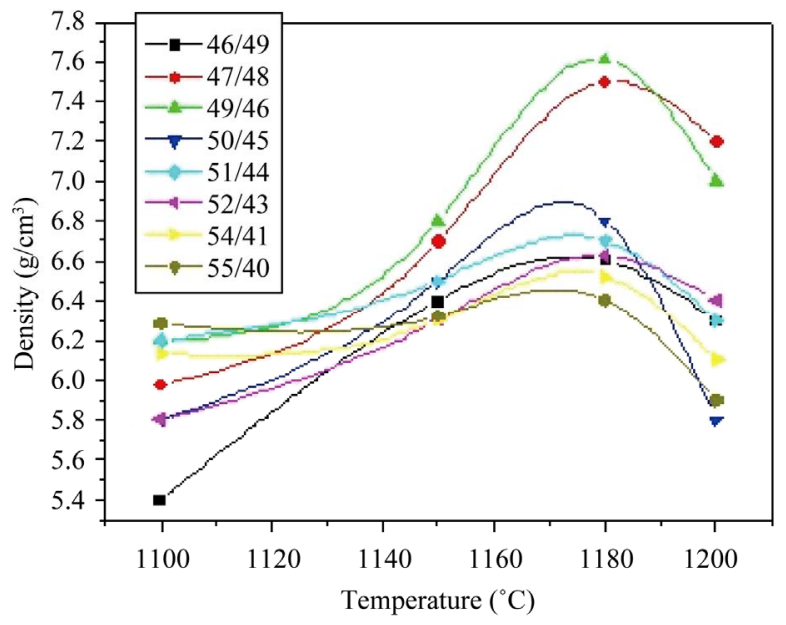

Figure 3. Effect of sintering temperature on density for $\mathrm{Pb}\left[\mathrm{Zr}_{\mathrm{x}} \mathrm{Ti}_{0,95-\mathrm{x}}\left(\mathrm{Mo}_{1 / 3} \mathrm{In}_{2 / 3}\right)_{0.05}\right] \mathrm{O}_{3}$.

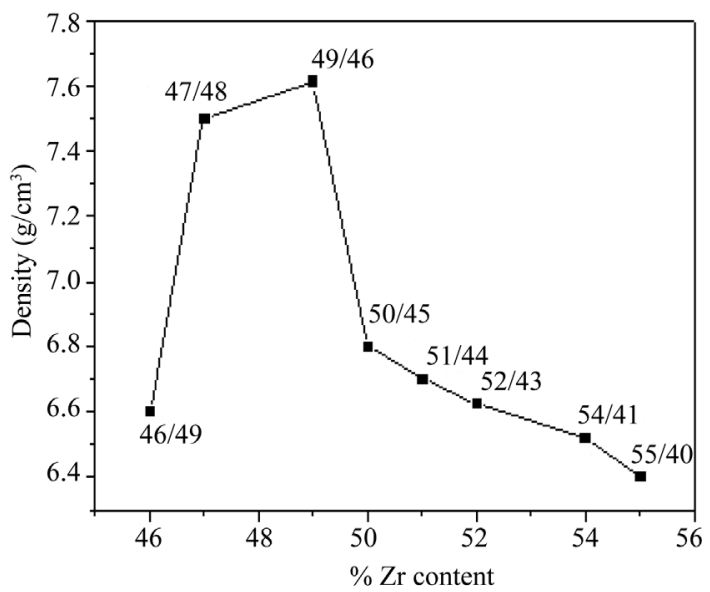

Figure 4. Evolution of density as a function of the concentration of $\mathrm{Zr} \%$ [20].

value of $7.61 \mathrm{~g} / \mathrm{cm}^{3}$ (94.18\% of theoretical density) at $\mathrm{Zr}=$ $49 \%$ (sample No. 3) and then it decreases [20].

Figure 5 shows the variation of the porosity for different samples depending on the concentration of $\mathrm{Zr} \%$ and the sintering temperature of $1180^{\circ} \mathrm{C}$, noting that the porosity decreases until itreaches the minimum value $\mathrm{p}=$ $5.81 \%$ for $\mathrm{Zr}=0.49$ (sample No. 3) and then it increases.

The parameters of the lattice were determined from the triplets (200) by using a nonlinear least squares method [27]. The $a_{R}$ - parameter of the rhombohedral phase and the $a_{T}$-parameter, $c_{T}$-parameter, and the tetragonality $\left(c_{T} / a_{T}\right)$ of the tetragonal phase of

$\mathrm{Pb}\left[\mathrm{Zr}_{\mathrm{x}} \mathrm{Ti}_{0,95-\mathrm{x}}\left(\mathrm{Mo}_{1 / 3} \mathrm{In}_{2 / 3}\right)_{0.05}\right] \mathrm{O}_{3}$ ceramics are plotted as a function of the ratio of $\mathrm{Zr} / \mathrm{Ti}$ in Figure 6 . The results showed that the parameters of the lattice of the tetragonalphase changed when the ratio of $\mathrm{Zr} / \mathrm{Ti}$ was modified. While the value of the $a_{T}$ parameter increased, the one of $c_{T}$ parameter decreased and the $a_{R}$ parameter of 


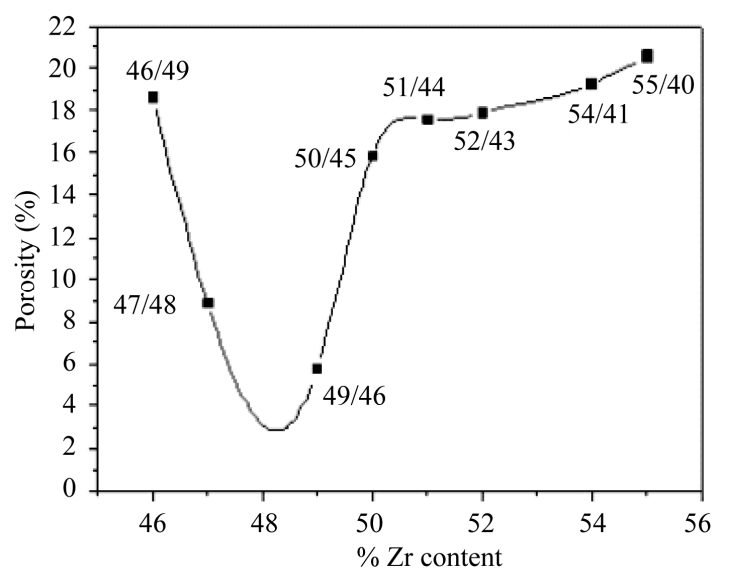

Figure 5. The variation of porosity as a function of the concentration of $\mathrm{Zr} \%$ for $\mathrm{Pb}\left[\mathrm{Zr}_{\mathrm{x}} \mathrm{Ti}_{0.95-\mathrm{x}}\left(\mathrm{Mo}_{1 / 3} \mathrm{In}_{2 / 3}\right)_{0.05}\right] \mathrm{O}_{3}$ (for a sintering temperature about $\left.1180^{\circ} \mathrm{C}\right)[20]$.

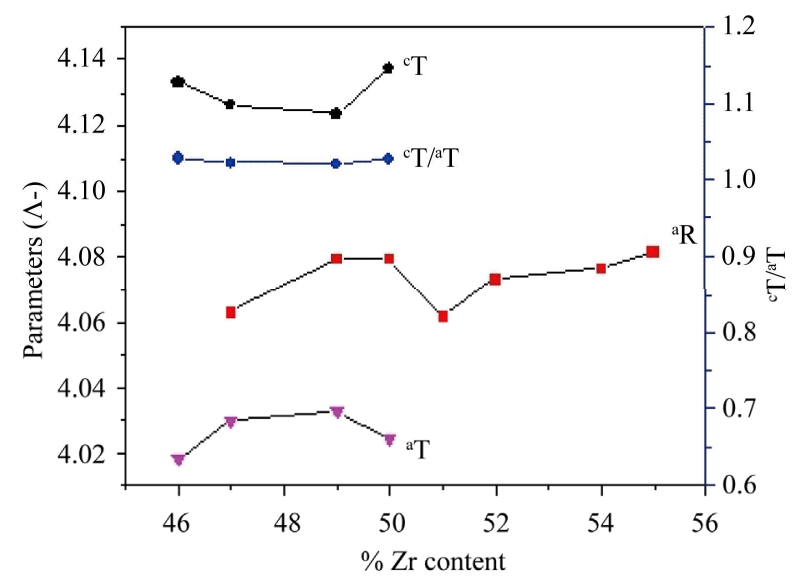

Figure 6. The parameters of the lattice of

$\mathrm{Pb}\left[\mathrm{Zr}_{\mathrm{x}} \mathrm{Ti}_{0,95-\mathrm{x}}\left(\mathrm{Mo}_{1 / 3} \mathrm{In}_{2 / 3}\right)_{0.05}\right] \mathrm{O}_{3}$ ceramics as a function of composition(for a sintering temperature about $1180^{\circ} \mathrm{C}$ ) [20].

the rhombohedral phase increased. The resulting values of the parameters of the lattice of the tetragonal phase showed that the $c_{T} / a_{T}$ axial ratio is decreased as $a_{T}$ it is increased and $c_{T}$ is decreased. The values of the parameters of the lattice were revealed to be practically the same as those which previously studied [28,29].

Figure 7 gives the SEM micrographs of free surfaces of the specimens sintered at $1000^{\circ} \mathrm{C}-1180^{\circ} \mathrm{C}$ for $2 \mathrm{~h}$. From these images, small crystallites with large pores for specimens sintered at $1000^{\circ} \mathrm{C}$ Figure 7(a) were noticed. As the sintering temperature increased, the grain grew and the average grain size increased slightly. Whereas, the number and the size of the pores is decreased. The grain size exponentially increased with the increase of temperature and this can be well explained by the phenomenological kinetic grain grow equation [30]. The average grain size is $1.15 \mu \mathrm{m}$ at temperature $1000^{\circ} \mathrm{C}$ which increases to $1.56 \mu \mathrm{m}$ at temperature $1180^{\circ} \mathrm{C}$ [20].
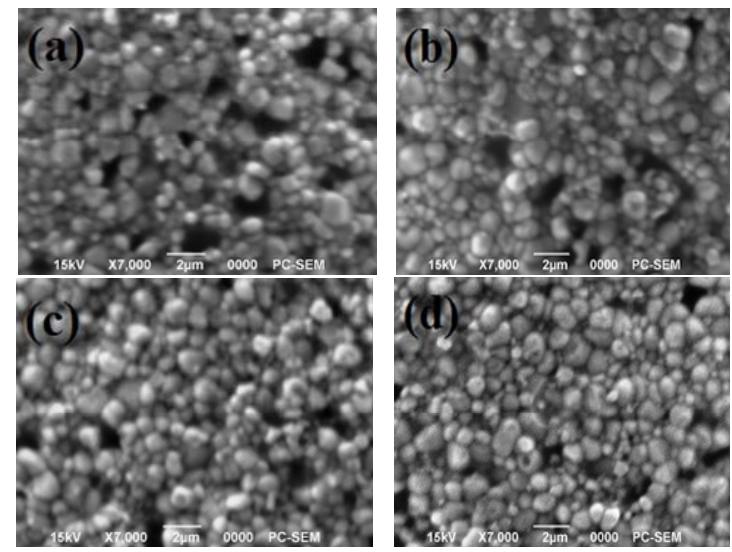

Figure 7. SEM micrographs for

$\mathrm{Pb}\left[\mathrm{Zr}_{0.50} \mathrm{Ti}_{0.45}\left(\mathrm{Mo}_{1 / 3}, \mathrm{In}_{2 / 3}\right)_{0.05}\right] \mathrm{O}_{3}$ ceramics sintered at (a) $1000^{\circ} \mathrm{C}$, (b) $1100^{\circ} \mathrm{C}$ (c) $1150^{\circ} \mathrm{C}$ and (d) $1180^{\circ} \mathrm{C}$.

\subsection{Dielectric and Piezoelectric Properties}

The dielectric properties at room temperature are plotted as a function of the $\mathrm{Zr} / \mathrm{Ti}$ ratio in Figure 8. The $\varepsilon$ increase with the increase of $\mathrm{Zr} / \mathrm{Ti}$ ratio. It achieves a maximum value of 1331.955 only when $\mathrm{x}=0.49$ and then it decreases significantly as the $\mathrm{Zr} / \mathrm{Ti}$ ratio increases further. The $\tan \delta$ shows an inverse trend and reaches the minimum value of 0.00205 when $\mathrm{x}=0.49$.

The temperature dependence of the dielectric constant for $\mathrm{Pb}\left[\mathrm{Zr}_{\mathrm{x}} \mathrm{Ti}_{0.95-\mathrm{x}}\left(\mathrm{Mo}_{1 / 3} \mathrm{In}_{2 / 3}\right)_{0.05}\right] \mathrm{O}_{3}$ ternary ceramics at 1 $\mathrm{KHz}$ is shown in Figure 9. It is observed in all the compositions as the temperature increase, the value of dielectric constant increases and passes through a maximum (at $T_{C}$ ) and then decreases. The Curie temperature increased from $340^{\circ} \mathrm{C}$ to $440^{\circ} \mathrm{C}$ in our choosing composition. The maximum dielectric constant at MPB $(x=0.49)$ is about 7300.345 .

The variation in dielectric constant with frequency for $\mathrm{Pb}\left[\mathrm{Zr}_{\mathrm{x}} \mathrm{Ti}_{0.95-\mathrm{x}}\left(\mathrm{Mo}_{1 / 3} \mathrm{In}_{2 / 3}\right)_{0.05}\right] \mathrm{O}_{3}$ ternary ceramics is shown in Figure 10. The plots show that the dielectric constant decreases with an increase in frequency, showing dispersion in lower frequency rang. It attains a constant value and remains independent of frequency. Thereafter, all the samples reveal dispersion due to Maxwell-Wagner [31, 32] type interfacial polarization in agreement with Koop's phenomenological theory [33]. The high value of dielectric constant observed at lower frequencies can be explained on the basis of space charge polarization due to heterogeneous in structure like impurities, porosity and grain structure [34].

The electromechanical coupling factor $\left(k_{p}\right)$ and the piezoelectric coefficient $\left(d_{31}\right)$ are shown in Figure 11. These properties were also strongly influenced by the composition of the specimen. The highest $d_{31}$ of 94.965 $\mathrm{pC} / \mathrm{N}$ and $K_{p}$ of 0.513 were observed for the composition of $x=0.49$. Considering that the fact of this composition 


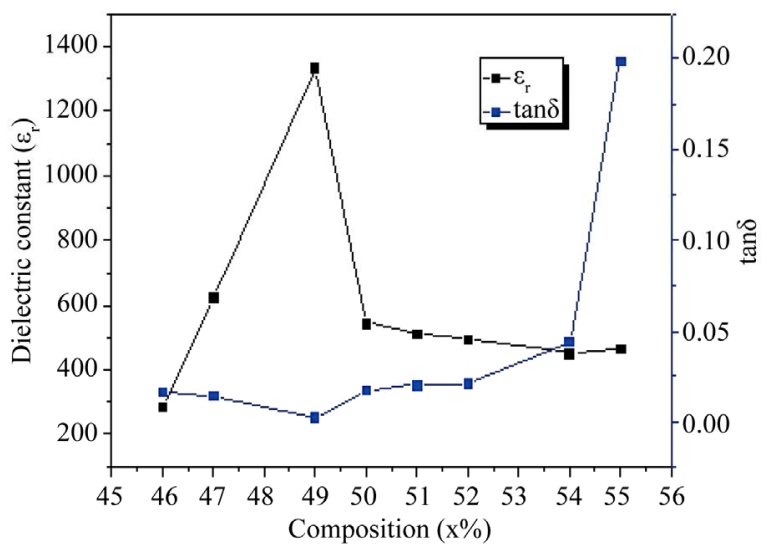

Figure 8. The dielectric constant $\varepsilon$ and the loss tangent (at room temperature, $1 \mathrm{KHz}$ ) for

$\mathrm{Pb}\left[\mathrm{Zr}_{\mathrm{x}} \mathrm{Ti}_{0,95-\mathrm{x}}\left(\mathrm{Mo}_{1 / 3} \mathrm{In}_{2 / 3}\right)_{0.05}\right] \mathrm{O}_{3}$ ceramics sintered at $1180^{\circ} \mathrm{C}$.

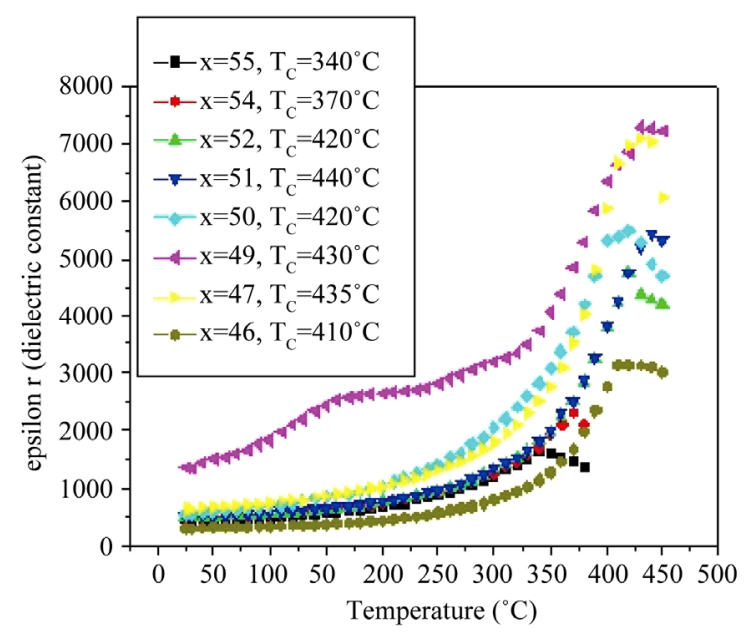

Figure 9. Temperature dependence of the dielectric constant for $\mathrm{Pb}\left[\mathrm{Zr}_{\mathrm{x}} \mathrm{Ti}_{0.95-\mathrm{x}}\left(\mathrm{Mo}_{1 / 3} \mathrm{In}_{2 / 3}\right)_{0.05}\right] \mathrm{O}_{3}$ ceramics sintered at $1180^{\circ} \mathrm{C}(1 \mathrm{KHz})$.

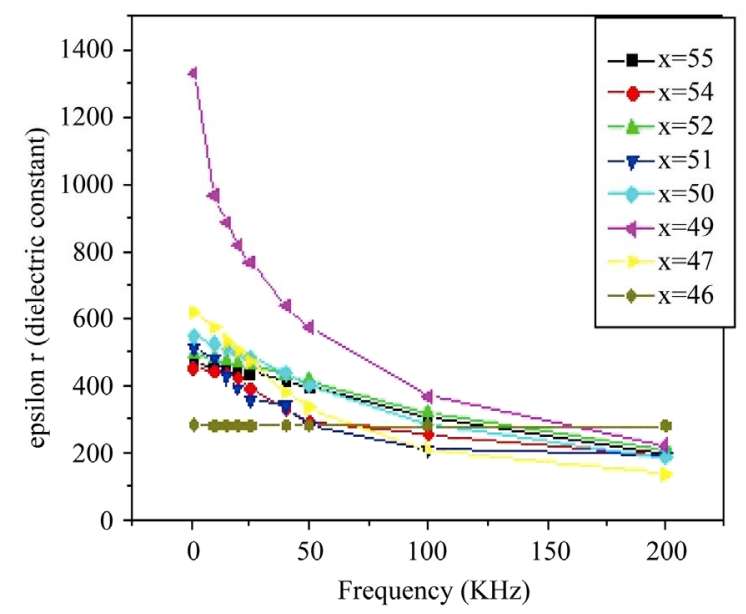

Figure 10. Variation of dielectric constant with frequency for $\mathrm{Pb}\left[\mathrm{Zr}_{\mathrm{x}} \mathrm{Ti}_{0,95-\mathrm{x}}\left(\mathrm{Mo}_{1 / 3} \mathrm{In}_{2 / 3}\right)_{0.05}\right] \mathrm{O}_{3}$ ceramics sintered at $1180^{\circ} \mathrm{C}$.

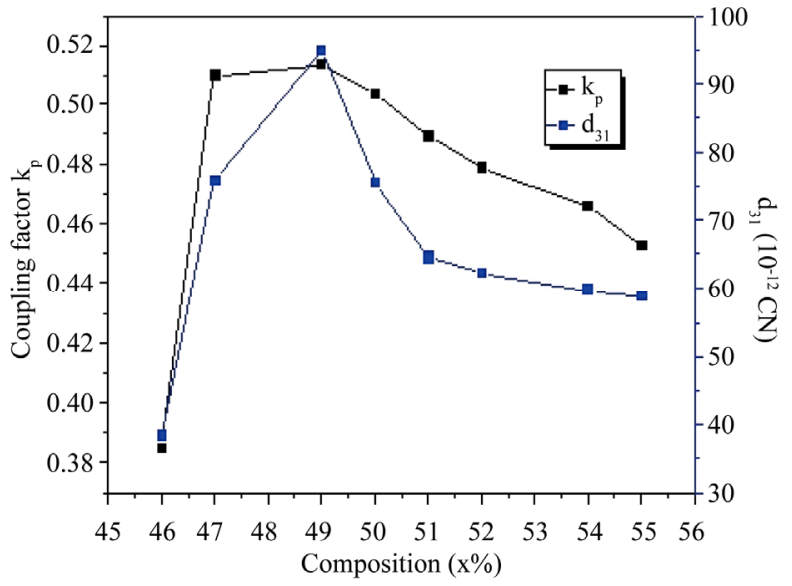

Figure 11. Variation of $K_{p}$ and $d_{31}$ for

$\mathrm{Pb}\left[\mathrm{Zr}_{\mathrm{x}} \mathrm{Ti}_{0.95-\mathrm{x}}\left(\mathrm{Mo}_{1 / 3} \mathrm{In}_{2 / 3}\right)_{0.05}\right] \mathrm{O}_{3}$ ceramics sintered at $1180^{\circ} \mathrm{C}$.

corresponds to the MPB and the maximum piezoelectric properties observed for this polycrystalline composition are reasonable. When the PZT content was varied away from the MPB, both the $d_{31}$ and $k_{p}$ value decreased asymmetrically. In the rhombohedral side, both the $d_{31}$ and $k_{p}$ value were decreased much more rapidly.

\section{Conclusions}

In this study, ceramics in the

$\mathrm{Pb}\left[\mathrm{Zr}_{\mathrm{x}} \mathrm{Ti}_{0.95-\mathrm{x}}\left(\mathrm{Mo}_{1 / 3} \mathrm{In}_{2 / 3}\right)_{0.05}\right] \mathrm{O}_{3}$ system (with $0.46 \leq \mathrm{x} \leq$ 0.55 ) were successfully prepared by a solid-state mixedoxide technique. The co-existence region was investigated by X-ray diffraction. The study of the morphotropic phase boundary has established that the phase transition from tetragonal to rhombohedral symmetry takes place at $\mathrm{x}=0.49$ and the width of the phase boundary that has been found to be in the range of $0.47 \leq \mathrm{x} \leq$ 0.50 at $1180^{\circ} \mathrm{C}$.

The lattice parameters $a_{T}$ and $c_{T}$ of the tetragonal structure and $a_{R}$ of the rhombohedral structure were found to change with composition. The effect of the sintering temperature on the density and grain size has been investigated. It was demonstrated that the grain size and the density increased with the increase of the sintering temperature. The optimum sintering temperature $\left(1180^{\circ} \mathrm{C}\right)$ corresponds to the maximum density. So, the minimum value of porosity is also corresponds to the better quality product.

The electrical and piezoelectric properties exhibit a compositional dependence. The samples showing the coexistence of morphotropic phase boundary (MPB) exhibit good properties. The results indicate that although this kind of ceramics displays good properties, further study is needed to improve their stabilities of the ceramics in order to be utilized in various temperature environments. 


\section{REFERENCES}

[1] T. Ezaki, S. Manuspiya, P. Moses, K. Uchino and V. Caraz, "Piezoelectric Transformers for a High Power Module," Journal of Materials Technology, Vol. 79, No. 19, 2004, pp. 79-82.

[2] B. Jaffe, W. R. Cook and H. Jaffe, "Piezoelectric Ceramics," Academic Press, New York, 1971.

[3] K. Uchino, "Piezoelectric Actuators 2008: Key Factors for Commercialization," Advanced Materials Research, Vol. 55-57, 2008, pp. 1-9.

[4] J. Valasek, "Piezoelectric and Allied Phenomena in Rochelle Salt," Physical Review, Vol. 17, No. 4, 1921, pp. 475-481.

[5] B. Wul, L. M. Goldman and C. R. Acad Sci, URSS, Vol. 46, 1945, p. 123.

[6] S. Pilgrim, M. Audrey, E. Sutherland and E. R. Winzer, "Diffuseness as a Useful Parameter for Relaxer Ceramics," Journal of the American Ceramic Society, Vol. 73, No. 10, 1990, pp. 3122-3125.

[7] S. Miga and K. Wojcik, "Investigation of the Diffuse Phase Transition in PLZT X/65/35 Ceramics, X $=7$ - 10," Ferroelectrics, Vol. 100, No. 1, 1989, pp. 167-173.

[8] K. L. Yadav, R. N. P. Choudhary and T. K. Chaki, "Structural, SEM and Dielectric Properties of PLZT," Journal of Materials Science, Vol. 27, No. 19, 1992, pp. 52445246.

[9] G. H. Heartling, "PLZT Electroopic Materials and Applications," Ferroelectrics, Vol. 75, 1987, pp. 25-55.

[10] L. Ramji, S. C. Sharma and D. Rajiv, "Piezoelectric Characteristics of Spray-Dried PZT Ceramics Modified by Isovalent, Supervalent and Subvalent Substitutions," Ferroelectrics, Vol. 100, 1989, pp. 43-55.

[11] G. H. Heartling, "Piezoelectric and Electrooptic Ceramics," In: R. C. Buchanan, Ed., Ceramics Materials for Electronics, Marcel Dekker, New York, 1991, pp. 139225.

[12] H. I. Chae, Y. S. Shin, K. J. Lim, H. D. Bae and D. W. Shin, "Vibration Level Dependence of Piezoelectric Constant in PT-PZ-PCN System Ceramic," Proceedings of the 4th Internationnal Conference on Properties of Applied Dielectrics and Materials, Brisbane, 3-8 July 1994, pp. 17-20.

[13] L. Wu, C. K. Liang and C. F. Shieu, "Piezoelectric Properties of $(\mathrm{Pb}, \mathrm{Sr})(\mathrm{Zr}, \mathrm{Ti}, \mathrm{Mn}, \mathrm{Zn}, \mathrm{Nb}) \mathrm{O}_{3}$ Piezoelectric Ceramic," Journal of Materials Science, Vol. 26, 1991, pp. 4439-4444.

[14] J. S. Kim, S. J. Kim, H. J. Kim, D. C. Lee and K. Uchino, "Piezoelectric and Dielectric Properties of $\mathrm{Fe}_{2} \mathrm{O}_{3}$-Doped $0.57 \mathrm{~Pb}\left(\mathrm{Sc}_{1 / 2} \mathrm{Nb}_{1 / 2}\right) \mathrm{O}_{3}-0.43 \mathrm{PbTiO}_{3}$ Ceramic Materials," Japanese Journal of Applied Physics, Vol. 38, 1999, pp. 1433-1437.

[15] D. J. Lee, S. S. Kwon, S. H. Jeong, K. J. Lim, S. G. Park, H. H. Kim and T. Y. Lim, "The Piezoelectric Characteristics of PZ-PT-PMS Ceramics with Addition of $\mathrm{CeO}_{2}$ for Large Displacement Application," Proceedings of the IEEE International Conference on Conduction and Break- down in Solid Dielectric, Vlisterris, 22-25 June 1998, pp. 381-384.

[16] X. H. Zhu and Z. Y. Meng, "The Influence of the Morphotropic Phase Boundary on the Dielectric and Piezoelectric Properties of the PNN-PZ-PT Ternary System," Journal of Materials Science, Vol. 31, 1996, pp. 21712175.

[17] X. B. Guo, H. Y. Chen and Z. Y. Meng, The American Ceramic Society 103rd Annual Meeting, Indianapolis, 2000.

[18] S. Tashiro, M. Ikehiro and H. Igarashi, "Influence of Temperature Rise and Vibration Level on Electromechanical Properties of High-Power Piezoelectric Ceramics," Japanese Journal of Applied Physics, Vol. 36, 1997, pp. 3004 3009.

[19] IEEE Standard on Piezoelectricity, "IEEE Standard 1761978," Institute of Electrical and Electronic Engineers, New York, 1978.

[20] M. Abba, Z. Necira, N. Abdessalem and A. Bouterfaia, "Contribution to the Study of the Coexistence of Phases Tetragonal-Rhombohedral in Ceramic type PZT and General Form: $\mathrm{Pb}\left[\mathrm{Zr}_{\mathrm{x}} \mathrm{Ti}_{0,95-\mathrm{x}}\left(\mathrm{Mo}_{1 / 3} \mathrm{In}_{2 / 3}\right)_{0.05}\right] \mathrm{O}_{3}$," EPJ Web of Conferences, Vol. 29, 2012.

[21] G. H. Haerding and C. E. Land, Soc, Vol. 45, 1974, pp. $1-11$.

[22] T. Kala, "Study of the Influence of Manganese and Lanthanum Oxides on the Band Structure of $\mathrm{Pb}(\mathrm{Zr}, \mathrm{Ti}) \mathrm{O}_{3}$," Physica Status Solidi (a), Vol. 73, 1982, pp. 573-578.

[23] K. Kakegawa and J. Mohri, "A Compositional Fluctuation and Properties of $\mathrm{Pb}(\mathrm{Zr}, \mathrm{Ti}) \mathrm{O}_{3}$," Solid State Communicationgs, Vol. 24, No. 11, 1977, pp. 769-772.

[24] K. Kakegawa, J. Mohri, X. Shrasaki and K. Takahaashi, "Sluggish Pansition between Tetragonal and RhomboHedral Phases of $\mathrm{Pb}(\mathrm{Zr}, \mathrm{Ti}) \mathrm{O}_{3}$," Journal of the American Ceramic Society, Vol. 65, 1982, pp. 515-519.

[25] W. Hammer and M. J. Hoffmann, "Detailed X-Ray Diffraction Analyses and Correlation of Microstructural and Electromechanical Properties of La-Doped PZT Ceramics," Journal of Electroceramics, Vol. 2, 1998, pp. 7584.

[26] B. Jaff, W. R. Cook and H. Jaff, "Piezoelectric Ceramics,"Acadimic Press, London, 1971.

[27] B. D. Cullity, "Elements of X-Ray Diffraction," AddisonWesley Publishing Company, Inc., 1978.

[28] A. Boutarfaia, "Investigation of Co-Existence Region in Lead Zirconate Titanate Solid Solutions: X-Ray Diffraction Studies," Ceramics International, Vol. 26, No. 6, 2000, pp. 583-587.

[29] A. Boutarfaia, "Study of Solid State Reaction and the Morphotropic Phase Boundary in $\mathrm{Pb}(\mathrm{Zr}, \mathrm{Ti}) \mathrm{O}_{3}-\mathrm{Pb}(\mathrm{Fe} 1 / 5$, $\mathrm{Ni1} / 5, \mathrm{Sb} 3 / 5) \mathrm{O}_{3}$ Ceramics," Ceramics International, Vol. 27, No. 1, 2001, pp. 91-97. http://dx.doi.org/10.1016/S0272-8842(00)00047-X

[30] T. Senda and R. C. Bradt, "Grain Growth in Sintered $\mathrm{ZnO}$ and $\mathrm{ZnO}-\mathrm{Bi}_{2} \mathrm{O}_{3}$ Ceramics," Journal of the American Ceramic Society, Vol. 73, 1990, pp. 106-114.

[31] J. C. Maxwell, "Electricity and Magnetism," Oxford Uni- 
versity Press, London, 1973.

[32] K. W. Wagner, Annals of Physics, Vol. 40, 1993, p. 818.

[33] C. G. Koops, "On the Dispersion of Resistivity and Dielectric Constant of Some Semiconductors at Audiofrequencies," Physical Review, Vol. 83, 1951, pp. 121-124.
[34] S. Upadhyay and D. Omprakash, "Effect of Composition on Dielectric and Electrical Properties of the $\mathrm{Sr}_{1-x} \mathrm{La}_{x} \mathrm{Ti}_{1-x} \mathrm{Co}_{x} \mathrm{O}_{3}$ System," Bulletin of Materials Science, Vol. 19, 1996, pp. 513-525. 